\title{
Comparative Effects of Sole and Combined Application of Manure and Inorganic Fertilizer on Growth and Yield of Sweet Corn in Maiduguri, Nigeria *Yakaka K.M., Alkali A.
}

Department of Agricultural Technology, School of Agriculture and Applied Sciences. Ramat Polytechnic PMB1070 Maiduguri, Borno state, Nigeria

Corresponding Author : ykundili @gmail.com

\begin{abstract}
Article Info

Volume 8 Issue 1

Page Number: 112-116

Publication Issue :

January-February-2021

\section{Article History}

Accepted : 01 Jan 2021

A field experiment was conducted at the Teaching and Research Farm of Ramat Polytechnic Maiduguri, Borno state, Nigeria. to determine the comparative effects of manure and organic fertilizer on growth and yield of sweet corn. The experiment consisted of four treatments $0 \mathrm{~kg} \mathrm{ha}^{1}, 120 \mathrm{~kg} \mathrm{ha}^{-1}$ manure, $120 \mathrm{~kg}$ ha${ }^{1}$ inorganic fertilizer and $60 \mathrm{~kg} \mathrm{ha}^{-1}$ manure $+60 \mathrm{~kg} \mathrm{ha}^{-1}$ inorganic fertilizer. The treatments were laid in a complete randomized block design (RCBD) with three replicates. At 6 and 8 WAS a combination of $60 \mathrm{~kg} \mathrm{ha}^{-1}$ manure $60 \mathrm{~kg} \mathrm{ha}^{-1}$ inorganic fertilizer produced significantly taller plants than $120 \mathrm{~kg} \mathrm{ha}^{-1}$ manure and $120 \mathrm{~kg} \mathrm{ha}^{-1}$ inorganic fertilizer. At $10 \mathrm{WAS} 120 \mathrm{~kg} \mathrm{ha}^{-1}$ inorganic fertilizer produced significantly taller plants than $120 \mathrm{~kg} \mathrm{ha}^{-1}$ manure and $0 \mathrm{~kg} \mathrm{ha}^{-1}$. Combination of $60 \mathrm{~kg} \mathrm{ha}^{-1}$ manure $+60 \mathrm{~kg} \mathrm{ha}^{-1}$ inorganic fertilizer recorded highest grain yield than control $0 \mathrm{~kg} \mathrm{ha}^{-1}$ single manure $120 \mathrm{~kg} \mathrm{ha}^{-1}$ and $120 \mathrm{~kg}$ ha $^{-1}$ inorganic fertilizer.
\end{abstract}

Published : 10 Jan 2021
Keywords : Manure, Inorganic Fertilizer

\section{INTRODUCTION}

Soil fertility decline has been recognized as one of the major constraints in declining per capita food production in most parts of the Northern Nigeria. Intensive use of inorganic fertilizers and continuous cropping of soils have caused loss of soil organic matter, macro and micronutrients particularly Nitrogen $(\mathrm{N})$, Phosphorus $(\mathrm{P})$, and Potassium $(\mathrm{P})$ which results in poor yield (Mokwunye et al., 1996). The continuous use of inorganic fertilizers has not been completely useful because it has resulted in aggravating soil degradation in various forms such as loss of organic matter, increase soil acidity and nutrient imbalance. Due to its hazard and high cost attention is gradually shifting from the use of inorganic to organic forms of fertilization.

Organic manures has a direct role in plant growth as they contain all necessary macro and micro nutrients in available forms during the process of mineralization and also improves both physical and 
chemical properties of soil thus enhancing quality (El Shakweer et al., 1998).

Sweet corn commonly referred to as the standard sugary (su) corn, is thought to have originated from a mutation in the Peruvian race Chullp. Most certainly it was grown and used by Native Americans, Indians in pre - Columbian times. In sweet corn, the sugary gene prevents or retards the normal conversion of sugar into starch during endosperm development and the kernel accumulates a water soluble polysaccharide called "phytoglycogen". As a result the dry sugar kernels are wrinkled and glassy. The higher content of water soluble polysaccharide adds a texture quality factor in addition to sweetness. In the U.S, sweet corn is eaten in the immature milk stages and is one of the most popular vegetables. Sweet corn in the U.S is more important economically than its limited commercial production would indicate, because it is consumed directly as human food. Fresh in market or as canned and frozen products, rather than indirectly as livestock feed. The bulk of sweet corn production is confined to the northern tier of the States and to southern Florida as a winter crop. Sweet corn are very closely related with most scientists accepting that standard or sugary (sugene), sweet corn developed as a mutant of maize. This sweet corn accumulates about twice as much sugar (about 12\%) and eight to ten times more water soluble saccharides than normal maize has at the immature stage, when it is normally consumed as green meals.

Sweet corn being from the maize family like any other cereal is highly nutrient demanding especially for Nitrogen but plant nutrient are limiting in the sudan savannah due to low nutrient status of tropical soils resulting from continuous cultivation and intensive use of inorganic fertilizer which has led to increased acidity and excessive leaching of the soil nutrient (Steiner, 1991).
Organic manure on the other hand cannot meet up crop nutrient demand overlarge acreage of land especially over large area because of limited availability, low nutrient composition and high labour requirement. Therefore there is the need for a combined use of organic manure and inorganic fertilizer so as to achieve more benefits and yield returns as compared to the sole use of organic manure or inorganic fertilizer.

The objective of the study was to evaluate the combine effects of sole and combined applications of manure and inorganic fertilizer on growth and yield of sweet corn.

\section{MATERIALS AND METHODS}

Study was conducted in Ramat Polytechnic Teaching and Research Farm Maiduguri, the soil has been classified as TypicUstipsamment- it is physically characterized as sandy loam (Rayar, 1983) according to U.S.D.A soil classification (1975).

The treatments comprised of various levels of organic manure source and NPK 15-15-15 as inorganic source. The application was $120 \mathrm{kgN} \mathrm{ha}^{-1}$. The recommended nitrogen fertilizer rate for low fertility soils in Nigerian savannah is $120 \mathrm{kh} \mathrm{N} \mathrm{ha}^{-1}$ (Adeosun and Mohammed, 2010). The treatments were:

$0 \mathrm{~kg} \mathrm{ha}^{-1}$

$120 \mathrm{~kg} \mathrm{ha}^{-1}$ manure

$120 \mathrm{~kg} \mathrm{ha}^{-1}$ inorganic fertilizer

$60 \mathrm{~kg} \mathrm{~kg} \mathrm{ha}{ }^{-1}$ manure $+60 \mathrm{~kg} \mathrm{ha}^{-1}$ inorganic fertilizer.

The treatments were arranged in a Randomized Complete Block Design (RCBD) and replicated. The plot size was $4 \mathrm{~m}$ by $4 \mathrm{~m}$. The organic manure was collected from nearby school livestock farm and was applied one week before planting by broadcast method. 


\section{Agronomic practices}

The experimental plot were manually cleared and ridged at $75 \mathrm{~cm}$ apart. Two seeds of packaged sweet corn obtained from BOSADP were sown at $25 \mathrm{~cm}$ intra-row spacing. Seedlings were thinned to one plant per stand at two weeks after sowing (WAS). Half NPK 15:15:15 was applied at two WAS and the half was applied at five WAS using spot placement method. Weeding was done manually at 3, 6 and 9 WAS.

\section{Sampling and analysis}

The steady infiltration rate is $135 \mathrm{~mm} / \mathrm{hr}$ and average bulk density of the soil is $1.5 \mathrm{~g} / \mathrm{cm}^{3}$, (Grema and Hess, 1994). Soil samples were collected, prepared and labelled as prescribed by USEPA (2000). All other analysis was conducted at the Soil Science Laboratory of Department of Soil Science University of Maiduguri. Soil pH (soil reaction) was determined using the standard Electrometric method in water (1:2.5 distilled water suspensions); $\mathrm{pH}$ reading was taken with a glass electrode $\mathrm{pH}$ meter according to Thomas (1996).Soil Electrical Conductivity (EC) was determined using the Electrometric method in soilwater suspension (1:2.5); EC reading was taken with an EC meter according to Thomas (1996).Soil Exchangeable Acidity(EA) was determined by extracting the soil with KCL using the Extraction/Titration Method, McLean (1965).Soil Organic Carbon was determined using the wet oxidation method of Walkey and Black as reported by Sparks (1996).Soil Nitrogen (Total) was determined by Kjeldhal Method and Titrimery by Winkler, (1913) as described by Marc and Jacques (2006).Soil phosphorus was determined by Brey No. 1 Method, (Bray and Kurtz, 1945). Particle Size Analysis (Soil Texture) was determined by hydrometer method of Day, (1965) while exchangeable bases (cations) in the soil were extracted with $1 \mathrm{~N}$ neutral ammonium acetate ( $\mathrm{NH}_{4} \mathrm{OAC}$ ) buffer according to Sparks (1996). The concentrations of $\mathrm{Na}$ and $\mathrm{K}$ were determined with the flame photometer while that of $\mathrm{Ca}$ and $\mathrm{Mg}$ by Atomic Absorption Spectrophotometer (AAS).

\section{Growth and yield parameters}

Plant height was measured at 2,4,6,8 and 10 WAS from the base of plant to the tip of the tallest leaf using a measuring tape. At harvest the sweet corn were harvested from the net plot and cobs were air dried and shelled. Grains per plot were weighed using weighing balance.

\section{Data analysis}

All data collected were subjected to analysis of variance using the statistical analysis system (STATISTIX 8.), mean separation were carried out using Duncan Multiple Range Test (DMRT) at 5\% probability level.

\section{RESULTS AND DISCUSSION}

Table 1 : initial physical and chemical properties of soil at experimental site

\begin{tabular}{ll}
\hline Soil Parameters & Values \\
\hline $\mathrm{Ph}$ & 6.66 \\
Electrical Conductivity & $0.47 \mathrm{mS} / \mathrm{cm}$ \\
Sand & $66 \%$ \\
Silt & $12.47 \%$ \\
Clay & $21.53 \%$ \\
$\mathrm{~K}^{+}$ & $2.23 \mathrm{cmolkg}^{-1}$ \\
$\mathrm{Ca}^{2+}$ & $2.13 \mathrm{cmolkg}^{-1}$ \\
$\mathrm{Mg}^{2+}$ & $4.03 \mathrm{cmolkg}^{-1}$ \\
$\mathrm{Na}^{+}$ & $3.05 \mathrm{cmolkg}^{-1}$ \\
$\mathrm{~A} 1 \& \mathrm{H}$ & $1.23 \mathrm{cmolkg}{ }^{-1}$ \\
Organic Matter (OM) & $3.02 \%$ \\
Organic Carbon (OC) & $1.75 \%$ \\
Nitrogen (N) & $0.80 \%$ \\
Phosphorus (P) & 5.48 \\
\hline
\end{tabular}

Results for physical and chemical properties of the soil shown in table 1 shows the soil is slightly acidic 1 in $\mathrm{pH}$ low in organic carbon, available $\mathrm{P}$ and Nitrogen. 
TABLE 2 : Effects of sole and combined application of manure and inorganic fertilizers on growth and yield parameters of sweet corn

\begin{tabular}{|c|c|c|c|c|c|c|}
\hline Treatments & 2WAS & $\begin{array}{l}\text { Plant } \\
\text { 4WAS }\end{array}$ & $\begin{array}{l}\text { Height } \\
\text { 6WAS }\end{array}$ & $\begin{array}{l}\text { (cm) } \\
\text { 8WAS }\end{array}$ & 10WAS & $\begin{array}{l}\text { Grain yield } \\
\left(\mathrm{t} \mathrm{ha}^{-1}\right)\end{array}$ \\
\hline Control $\left(0 \mathrm{~kg} \mathrm{~N} \mathrm{ha}^{-1}\right)$ & $24.02^{\mathrm{a}}$ & $64.15^{b}$ & $102.16^{\mathrm{d}}$ & $126.33^{c}$ & $142.54^{\mathrm{c}}$ & $1,61^{\mathrm{c}}$ \\
\hline $120 \mathrm{~kg} \mathrm{ha}^{-1}$ manure & $27.77^{a}$ & $84.68^{\mathrm{a}}$ & $140.88^{\mathrm{bc}}$ & $193.02^{\mathrm{b}}$ & $219.77^{b}$ & $3.50^{\mathrm{b}}$ \\
\hline $\begin{array}{l}120 \mathrm{~kg} \mathrm{ha}^{-1} \text { inorganic } \\
\text { fertilizer }\end{array}$ & $26.22^{\mathrm{a}}$ & $67.96^{b}$ & $131.36^{c}$ & $199.29^{\mathrm{ab}}$ & $199.64^{\mathrm{b}}$ & $5.39^{a}$ \\
\hline $\begin{array}{l}60 \mathrm{~kg} \mathrm{ha}^{-1} \text { manure }+60 \\
\mathrm{~kg} \mathrm{ha}^{-1} \text { inorganic } \\
\text { fertilizer }\end{array}$ & $26.10^{\mathrm{a}}$ & $80.82^{\mathrm{a}}$ & $153.00^{\mathrm{a}}$ & $207.65^{\mathrm{a}}$ & $214.82^{\mathrm{ab}}$ & $5.00^{\mathrm{a}}$ \\
\hline SE-+ & 2.03 & 2.78 & 3.54 & 3.94 & 5.30 & 0.39 \\
\hline
\end{tabular}

Means with the same letter(s) are not significantly different at 5\% level of probability using Duncan Multiple Range Test (DMRT). WAS: Weeks after Sowing

The results from the above Table shows that at 2,4 and 6 WAS $120 \mathrm{kgha}^{-1}$ manure had taller plants as compared to both control and $120 \mathrm{~kg} \mathrm{ha}^{-1}$ inorganic fertilizer. The tallest plant at 8 WAS was observed in plots treated with $120 \mathrm{~kg} \mathrm{ha}^{-1}$ inorganic fertilizer. At 10WAS $120 \mathrm{~kg} \mathrm{ha}^{-1}$ manure was significantly taller plants than $120 \mathrm{kgha}^{-1}$ inorganic fertilizer. The observed significant performance in plant height with the application of manure and inorganic fertilizer could be attributed to the essential nutrient elements contained in the manure and the inorganic fertilizer that are associated with photosynthetic efficiency. The tallest plant height was observed in plots treated with a combination of $60 \mathrm{~kg} \mathrm{ha}^{-1}$ manure and $60 \mathrm{~kg} \mathrm{ha}^{-1}$ inorganic fertilizer which shows a positive interaction between treatment combinations. This interaction resulted in improved nutrient release, uptake and assimilation by sweet corn thus resulting in higher growth. This finding is in agreement with the report of Okoruwa (1998), who observed significant increase in dry matter accumulation in maize with successive increase in organic manure and inorganic fertilizer rates.
Ayoola and Makinde (2009) reported better height of maize tested with organo-mineral fertilizer. In another research Chandrasekhar et al. (2000) observed that the application of poultry manure with inorganic fertilizer produced taller plants than the plants with sole application of inorganic fertilizer. The rapid release of nutrient from the inorganic fertilizer and the slow release from the manure give a good combination for the effective growth and development of sweet corn.

\section{CONCLUSION}

In conclusion plots treated with combination of $60 \mathrm{~kg}$ $\mathrm{ha}^{-1}$ manure and $60 \mathrm{~kg} \mathrm{ha}{ }^{-1}$ inorganic fertilizer produced significantly taller pants and higher yield compared to sole treatments of either manure or inorganic fertilizer. It is now recognized that the manure is the most desirable source of organic matter which improves soil fertility by adding major and most essential nutrients required by plants as well as organic matter which is known to improve soil moisture and nutrients retention (Farhad et al., 2009).

At 4, 6 and 10WAS $120 \mathrm{~kg}^{\mathrm{ha}}{ }^{-1}$ manure produced significantly taller plants than other treatments. 


\section{REFERENCES}

[1]. Adeosun, J.O. and Mohammed, S.G.(2010). Improved agronomic practices for cereal production. In: Ajeibe, H. A., Mohammed, S.G.,Adeosun, J.O. and Ihedioha, D.(Eds).Farmers guide to increased productivity of improvedlegume-cereal cropping sysytemsin the savannas of Nigeria.IITA, Ibadan, Nigeria. 104pp.

[2]. Ayoola. O.T.and Makinde, E.A. (2008). Performance of green maize and soil nutrients changeswith fortified cattle dung. African journal of plant science. 2 (3): 19-22

[3]. Bray, R.H. and Kurtz, L.T. (1945). Determination of total, organic and available forms of phosphorus in soils. Soil Sci., 59, 3945.

[4]. Chandrasekhar, G.K., Harlapur, S.I., Muralikrishna, S. and Girish, G. (2000). Response of maize (zea mays L.) to organic manureswith organic fertilizers. Karnataka journal of agricultural science 13 (1): 144-146.

[5]. El shakweer, M.H.A., El Sayad, E.A. and Ewees, M.S.A.(1998). Soil and plant analysis as a guide for interpretation of the improvement efficiency of organic conditioners added to different soils in Egypt. Communications in soil science and plant analysis 29: 2067-2088.

[6]. Farhad, M., Saleem, M.F. (2009). Effect of poultry manure levels on the productivity of spring maize. The journal of Animal and plant sciences 19 (3) : 122-125.

[7]. Grema, A.K. and Hess, T.M. (1994).Water balance use of pearl millet-cowpea intercrop in Northeast Nigeria. Agric Water Management, 26: 169-185.

[8]. Marc, P. And Jacques, G. (2006).Handbook of Soil Analysis Mineralogical, Organic and Inorganic Methods.Pages 334-349.

[9]. McLean, E.O. (1965). Aluminium.In method of soil analysis (ed. C.A. Black), pp. 978-998, Agronomy No.9.
[10]. Mokwunye, A.U., De Jager, A. and Smaling, E.M.A. (1996). Restoring and maintaining the productivity of west Africa soils: keys to sustainable development. International Fertilizer Development Center (IFDC), Muscle Shoals, Alabama. 94A.

[11]. Okoruwa, E.A.(1998). Effects of NPK fertilizer and inorganic manure on the growth and yield of maize (Zea mays L.) Hybrid. Crop Science journal. 22: 119-124

[12]. Rayar, A. J. (1983). University of Maiduguri Farm Development Planning Soil Survey Details. Consultancy Report Submitted to University of Maiduguri.

[13]. Sparks, D.L. (1996).Methods of soil analysis.Part 3.Chemical methods.SSSA and ASA.Madison W.I pp 555-547.

[14]. Steiner ,K.G. (1991). Overcoming soil fertility constraints to crop production in West Africa. Impact of traditional and improved cropping systems on soil fertility. pp.69-91.

[15]. Thomas, G.W. (1996). Sol pH and soil acidity. In: Sparks DL (ed) Methods of soil analysis. Part 3.Chemical methods.SSSA and ASA.Madison, WI pp.475-490.

[16]. Winkler, L.W. (1913) Beitragzur titrimetrishen bestimmung des ammoniaks.Z Angew. Chem., 26, 231-232.

\section{Cite this article as :}

Yakaka K.M., Alkali A., "Comparative Effects of Sole and Combined Application of Manure and Inorganic Fertilizer on Growth and Yield of Sweet Corn in Maiduguri, Nigeria", International Journal of Scientific Research in Science, Engineering and Technology (IJSRSET), Online ISSN : 2394-4099, Print ISSN : 2395-1990, Volume 8 Issue 1, pp. 112116, January-February 2021. Available at doi : https://doi.org/10.32628/IJSRSET218122 Journal URL : http://ijsrset.com/IJSRSET218122 